\title{
THE EFFECT OF PITUITARY GROWTH HORMONE IN DWARFISM WITH OSSEOUS RETARDATION AND HYPOGLYCEMIA AND IN A CRETIN TREATED WITH THYROID ${ }^{1}$
}

\author{
By ROGER A. LEWIS, ROBERT KLEIN, AND LAWSON WILKINS
}

\author{
(From the Department of Pediatrics, The Johns Hopkins University School of Medicine \\ and the Harriet Lane Home of the Johns Hopkins Hospital, Baltimore)
}

(Submitted for publication October 7, 1949; accepted December 5, 1949)

The chemistry and physiology of pituitary growth hormone have recently been reviewed by $\mathrm{Li}$ and Evans (1). Pure samples of growth hormone have been prepared by $\mathrm{Li}$ and coworkers from bovine pituitary glands ( 2 ) and by Wilhelmi and coworkers from a similar source by a somewhat different method (3). This hormone has been prepared and made available to a number of workers for metabolic investigation on human subjects. ${ }^{2}$

While the recently purified growth hormone causes linear growth, weight gain and nitrogen retention in both rats and dogs (1), no such effect has been reported in humans (4). The increase in inorganic phosphate which is characteristic of growth, has been produced in rats by injection of growth hormone (1) and has been observed in humans with an increased endogenous supply of growth hormone (5), but not in human subjects treated with growth hormone (4). In fact, most individuals who have been treated with growth hormone, have shown an increased excretion of nitrogen, slight elevation of temperature and symptoms of malaise.

A dwarf with osseous retardation and hypoglycemia was selected for these studies because it was surmised that such an individual might be more sensitive to the hormone. Since it seemed possible that some of the findings in this case might be attributable to the presence of thyrotropic hormone in the preparation, an athyrotic cretin, rendered euthyroid by the administration

1 This work was made possible by a grant from the American Cancer Society for studies on the relationship of the pituitary hormones, thyroid hormone, and the steroid hormones of the adrenal glands and gonads to normal and abnormal growth, and by a grant from the Commonwealth Fund for the study of endocrine problems in childhood.

2 Kindly furnished by Dr. John R. Mote, the Armour Laboratories, Chicago, Ill. of thyroid, was selected for the second study in order to eliminate the possibility of a thyroid response.

\section{METHODS}

Both patients were placed on a constant diet which approximated the normal intake as closely as possible. The protein, fat, and carbohydrate composition of the diet was calculated from conventional tables and the nitrogen content checked by direct analysis. Each patient was given $1 \mathrm{gm}$. of salt daily to use in seasoning food. Because of the variable warm weather the fluid intake was not restricted.

Blood was taken for chemical analysis before breakfast. Urine was collected in 24 hour periods and preserved with acetic acid. The determinations were made on daily specimens except in the case of the steroid analyses which were made on pooled specimens.

The chemical determinations were performed by conventional methods (6) with the exception of sodium and potassium and urinary steroids. A flame photometer (7) was used to measure sodium and potassium. The 17ketosteroid excretion was measured by colorimetric estimation with dinitrobenzene in alcoholic alkaline solution (8) and the neutral reducing lipids of the urine were measured by the phosphomolybdic acid color reaction (9) performed on extracts obtained by chloroform extraction and subjected to benzene-water partition (10) but not Girard's separation.

Urinary excretion of nitrogen was estimated colorimetrically after digestion with sulfuric acid and nesslerization, and the nitrogen content of the diet by the $\mathrm{Kjel}$ dahl method (6). The nitrogen content of the stools was calculated as $10 \%$ of the nitrogen content of the diet since it has been shown that when the protein content of the diet is normal this is "reasonably accurate" (11).

The growth hormone used in these experiments was prepared from beef pituitaries (2). The potency of the preparation used was equivalent to $110 \pm 6 \%$ of that of the standard preparation as assayed by the manufacturers. ${ }^{3}$

\section{CASE HISTORIES}

Dwarfism with osseous retardation and hypoglycemia: The patient (H. L. H. A 67430) was a boy aged $61 / 2$

3 Lot. No. 6 PKR3, serial No. H 1902. Purified growth hormone assays $204 \pm 36 \%$ of the standard noted above. 
years. He had been stunted in growth from the age of six months. At the age of five years he started to have hypoglycemic episodes. He was well proportioned but had a height age of only 15 months and weighed only 19 pounds. He showed no evidence of hypothyroidism, being alert and energetic, and having good color and warm, moist skin. X-rays showed a bone age of less than three years. Blood chemical and urine studies are shown in Table I. Fasting blood sugar varied from 88 to $44 \mathrm{mg} . \%$. The serum electrolytes were normal. He was placed on a diet of $25 \mathrm{gm}$. protein, $35 \mathrm{gm}$. fat and $110 \mathrm{gm}$. carbohydrate or 860 calories.

Cretinism: The patient (H. L. H. A 3914) was a girl aged 17 years. When first examined at the age of six years she had a height age of 15 months and a bone age of three months. There were epiphysial dysgenesis, hypercholesterolemia, carotinemia, and other characteristic signs of hypothyroidism. From the age of six years she had received fairly continuous treatment with thyroid extract in a dose varying from $1 \frac{1}{2}$ to $21 / 2$ grains daily. Radioactive iodine did not localize in the thyroid region even when thyrotropic hormone was administered. At the time of these studies she was taking $11 / 2$ grains of thyroid and appeared to be euthyroid. Basal metabolism was $-13 \%$ of normal. Blood chemical findings and urinary studies are shown in Table II. She was placed on a diet of $60 \mathrm{gm}$. protein, $60 \mathrm{gm}$. fat and $180 \mathrm{gm}$. carbohydrate or 1,500 calories.

\section{RESULTS}

Results of treatment with growth hormone in the case of dwarfism are summarized in Table I. More outstanding than these changes was the clinical response of the patient. He developed anorexia, listlessness and nausea when the dose of hormone was increased to $15 \mathrm{mg}$. a day after 11 days on smaller doses. When the dose was raised to $20 \mathrm{mg}$. a day he vomited and although the dose was reduced to $10 \mathrm{mg}$. a day he did not recover his well-being until a week after the hormone was discontinued.

The malaise was accompanied by a slight elevation of temperature from a previous daily maximum of $36.6^{\circ} \mathrm{C}$. to a high of $37.7^{\circ} \mathrm{C}$. rectal. There was no local reaction and no evidence of infection. With the anorexia there was a decrease in nitrogen intake so that although there was no rise in urinary nitrogen excretion, there was a negative nitrogen balance and a loss of weight. Five days after the hormone was discontinued, the patient reverted to the previous state of nitrogen balance and weight equilibrium.

TABLE I

Effect of growth hormone in a case of dwarfism with osseous retardation and hypoglycemia

\begin{tabular}{|c|c|c|c|c|c|c|c|c|c|c|c|c|c|}
\hline $\begin{array}{l}\text { No. } \\
\text { days } \\
\text { each } \\
\text { period }\end{array}$ & $\begin{array}{c}\text { Daily } \\
\text { dose of } \\
\text { growth } \\
\text { hormone }\end{array}$ & $\begin{array}{c}\text { Temp- } \\
\text { erature } \\
\text { maximum }\end{array}$ & $\begin{array}{l}\text { Weight } \\
\text { at end } \\
\text { of the } \\
\text { period } \\
(\mathbf{k g} .) \\
\mathbf{8 . 6 *}\end{array}$ & $\begin{array}{c}\text { Average } \\
\text { daily } \\
\text { caloric } \\
\text { intake } \\
\ddagger\end{array}$ & $\begin{array}{c}\text { Average } \\
\text { daily } \\
\text { nitrogen } \\
\text { intake }\end{array}$ & $\begin{array}{c}\text { Urine } \\
\text { nitrogen } \\
+10 \% \\
\text { diet } \\
\text { nitrogen }\end{array}$ & $\begin{array}{c}\text { Average } \\
\text { daily } \\
\text { nitrogen } \\
\text { balance }\end{array}$ & $\begin{array}{c}\text { Average } \\
\text { urine } \\
\text { phos- } \\
\text { phate }\end{array}$ & $\begin{array}{c}\text { Average } \\
\text { urine } \\
\text { creat- } \\
\text { inine }\end{array}$ & $\begin{array}{c}\text { Average } \\
\text { urine } \\
\text { creat- } \\
\text { ine }\end{array}$ & $\begin{array}{c}\text { Serum } \\
\text { choles- } \\
\text { terol } \\
\text { level }\end{array}$ & $\begin{array}{l}\text { Serum } \\
\text { phos- } \\
\text { phate } \\
\text { level }\end{array}$ & $\begin{array}{l}\text { Serum } \\
\text { alkaline } \\
\text { phoo- } \\
\text { phatase }\end{array}$ \\
\hline $\begin{array}{c}\text { days } \\
5\end{array}$ & $\begin{array}{c}m g . \\
0\end{array}$ & $\begin{array}{l}{ }^{\circ} \mathrm{C} . \\
36.6\end{array}$ & 8.6 & $\begin{array}{l}\text { cal. } \\
843\end{array}$ & $\begin{array}{l}g m . \\
4.2\end{array}$ & $\begin{array}{l}g m . \\
3.3\end{array}$ & $\begin{array}{l}g m . \\
+.9\end{array}$ & $\begin{array}{l}m g . \\
240\end{array}$ & $\begin{array}{l}\text { me. } \\
149\end{array}$ & $\begin{array}{r}m g . \\
92\end{array}$ & $\begin{array}{c}m g . \% \\
320\end{array}$ & $\begin{array}{c}m g . \% \\
4.8\end{array}$ & $\begin{array}{l}\text { units } \\
8.4\end{array}$ \\
\hline 5 & 0 & 36.1 & 8.7 & 845 & 4.8 & 4.1 & +.7 & 305 & 169 & 155 & 320 & 4.8 & 7.6 \\
\hline 5 & 11 & 36.4 & 8.5 & 869 & 4.8 & 4.3 & +.5 & 298 & 159 & 167 & - & - & - \\
\hline 5 & 35 & 37.0 & 8.5 & 794 & 4.0 & 4.1 & -.1 & 299 & 161 & 142 & 296 & 4.4 & 7.6 \\
\hline 5 & 70 & 37.1 & 8.3 & 773 & 3.5 & 3.3 & +.2 & 255 & 117 & 141 & 186 & 4.4 & 8.0 \\
\hline 5 & 95 & 37.6 & 8.1 & 738 & 3.2 & 3.5 & -.3 & 232 & 157 & 121 & 156 & 5.4 & 8.2 \\
\hline 5 & 60 & 37.7 & 7.8 & 708 & 3.0 & 3.3 & -.3 & 250 & 135 & 98 & - & - & - \\
\hline 5 & 40 & 37.5 & 7.7 & 639 & 2.4 & 3.1 & -.7 & 221 & 152 & 101 & 146 & 4.2 & 7.8 \\
\hline 5 & 0 & 37.0 & 7.7 & 707 & 2.9 & 3.6 & -.7 & 174 & 147 & 83 & 388 & 4.4 & 6.8 \\
\hline 5 & 0 & 36.9 & 7.8 & 753 & 3.0 & 2.9 & +.1 & 181 & 157 & 80 & 270 & 4.4 & 5.6 \\
\hline 5 & $0 \dagger$ & 37.3 & 8.2 & 673 & 2.9 & 2.7 & +.2 & 210 & 168 & 90 & - & - & - \\
\hline
\end{tabular}

* Weight at the beginning of the first period.

$\dagger$ Methyl testosterone $25 \mathrm{mg}$. day.

$\ddagger$ Includes only that portion of the diet which was ingested and retained. 


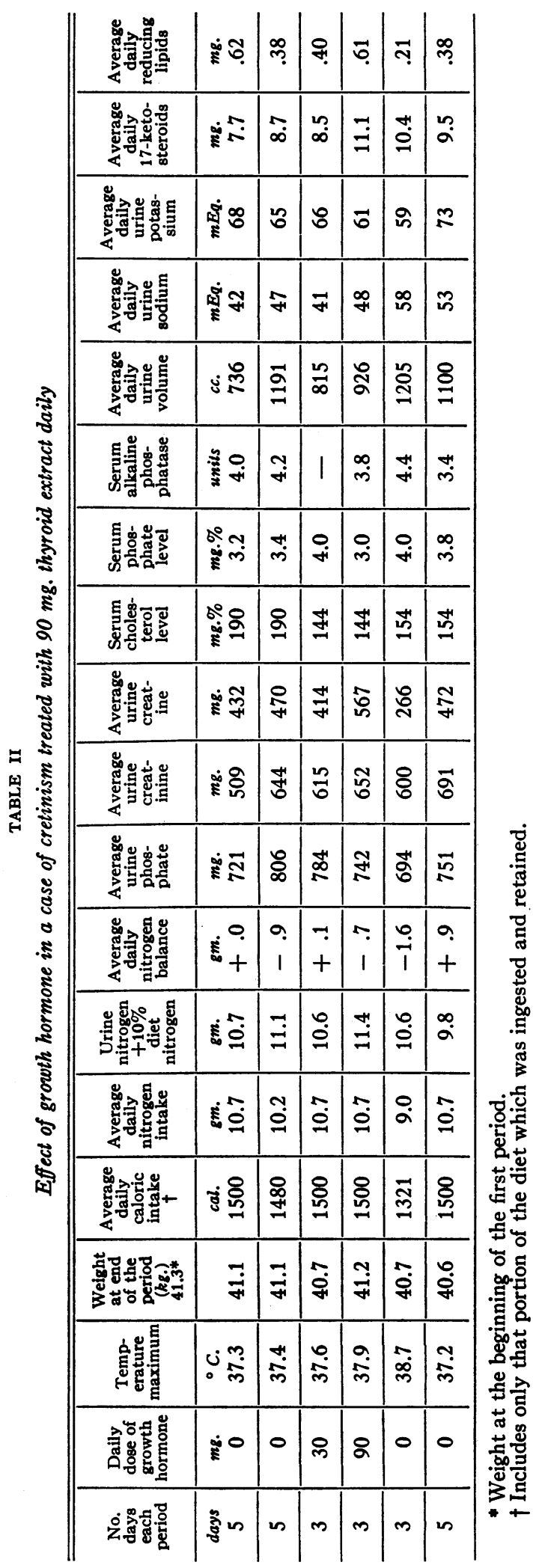


There was no sustained increase in the serum sugar, phosphorous or alkaline phosphatase level. The most striking change was a marked fall in the serum cholesterol level from $320 \mathrm{mg} . \%$ to $146 \mathrm{mg} . \%$ and a return after the cessation of treatment to the previous higher than normal level.

The results of treatment with growth hormone in the case of cretinism are shown in Table II. Just as in the case of dwarfism, the patient developed anorexia, nausea, and vomiting complicated in this instance by severe headache. This reaction commenced on the sixth day of treatment when the dose reached a level of $100 \mathrm{mg}$. a day. The temperature rose from a previous maximum of $37.6^{\circ} \mathrm{C}$. to $38.7^{\circ} \mathrm{C}$. rectal. The patient returned to her normal state two days after the hormone was discontinued.

In this experiment there was no significant change in the nitrogen balance except for the last two days of hormone administration and the one day following the cessation of therapy when the lowered intake and vomiting created a large negative balance even though the urinary nitrogen was not increased. During the last period there was a return to positive nitrogen balance. The urinary phosphate excretion did not rise with the urinary nitrogen excretion and in the last period when the urinary nitrogen decreased there was a rise in the urinary phosphate. As in the previous case, there was no sustained rise in serum inorganic phosphate or in serum alkaline phosphatase. The cholesterol level fell slightly during the treatment period but did not rise again to the pretreatment level during the short observation period following treatment with the hormone.

In this case additional studies were made of the urinary excretion of 17 -ketosteroid and neutral reducing lipids as well as sodium and potassium. The changes were not striking although there was a definite rise in 17-ketosteroid excretion when the dose of growth hormone was increased.

\section{DISCUSSION}

It is apparent from both of these experiments that the pituitary growth hormone preparation employed here did not cause weight gain, nitrogen retention, or a rise in serum inorganic phosphate such as has been reported to occur in species other than man (1). It did, however, produce a state of malaise characterized by fever and anorexia which resulted in weight loss and a negative nitrogen balance as has been the experience of other investigators working with human subjects (4).

The absence of any positive nitrogen retention or elevation of serum inorganic phosphate in a case of dwarfism with osseous retardation and hypoglycemia is very significant because such a patient should be sensitive to small doses of the hormones which may be diminished or absent.

The absence of nitrogen retention in a treated cretin indicates that the failure of growth hormone to promote nitrogen anabolism cannot be ascribed to the presence of thyrotropic hormone or to any indirect effect upon thyroid activity.

It is unlikely that the presence of small amounts of adrenocorticotropic hormone could account for the changes noted in these experiments since the adrenocorticotropic hormone contaminant at the maximum growth hormone administration was less than $5 \mathrm{mg}$. a day as measured by the standard preparation of the Armour Laboratories. However, adrenocorticotropic hormone usually produces an increase in nitrogen excretion (12) and the slightly increased excretion of 17 -ketosteroids in the second case is compatible with an increased output of adrenal cortical hormone. It is also quite possible that an increased adrenal cortical hormone output was produced by endogenous adrenocorticotropic hormone as a result of the toxic action of the growth hormone.

The consistent fall in the serum cholesterol level of both patients treated with growth hormone is of interest. In the athyrotic patient this decrease in cholesterol could not have been the result of thyrotropic hormone. A fall in the serum cholesterol has been reported with large doses of adrenocorticotropic hormone (13), but less than $5 \mathrm{mg}$. a day could not be responsible for this change. It is possible that the fall in the serum cholesterol level reflects the general decrease in body fat stores which takes place when growth hormone is administered to animals (14).

The failure of growth hormone to effect the same changes in the human as have been observed in laboratory animals may be the result of improper dosage, the development of an allergic state, a species peculiarity or the presence of im- 
purities in the preparation used. A similar phenomenon has been observed in dogs where a single large injection of growth hormone may cause increased nitrogen excretion with or without loss of weight (15). A further similarity between our findings and those reported by Bartlett and Gaebler in dogs is the occurrence of increased nitrogen excretion without an increase in the phosphate excretion. These authorities concluded that the negative nitrogen balance was the result of "impurities which are not chemically or biologically demonstrable." They noted further that the nitrogen loss was particularly likely to occur when single large doses of the hormone are administered and that the effect might be produced when either beef or hog pituitary growth hormone was employed.

The production of increased nitrogen excretion by the administration of growth hormone cannot be explained by the presence of contaminating thyrotropic hormone since it occurred in a cretin. It can be explained only partially by contamination with adrenocorticotropic hormone since it is unlikely that there was enough of this substance present in the doses given to produce the observed effects, and since even large doses of adrenocorticotropic hormone do not cause the discomfort and fever which have been observed regularly with growth hormone in the human.

\section{SUMMARY}

Pituitary growth hormone was administered to one patient with dwarfism, osseous retardation, and hypoglycemia and one patient with treated cretinism. Neither patient showed nitrogen retention or a rise in the serum inorganic phosphorous. Both patients developed fever and malaise. There was a slight increase in the urinary excretion of 17 -ketosteroids in the second case. Both cases showed a fall in the serum cholesterol level which was most marked in the patient with dwarfism. Both cases showed a slight decrease in phosphate excretion.

\section{ACKNOWLEDGMENTS}

The assistance of Miss Lee Helfgott, Miss June Hunt, and Mr. Henry Schulte in performing the chemical analyses is acknowledged. The help of Miss Ruth Fleischmann in operating the flame photometer is also gratefully acknowledged.

\section{BIBLIOGRAPHY}

1. Li, C. H., and Evans, H. M., The biochemistry of pituitary growth hormone, in: Recent Progress in Hormone Research, Vol. 3; Pincus, G., Editor. Academic Press, Inc., New York, 1948, p. 3.

2. Li, C. H., and Evans, H. M., Isolation of pituitary growth hormone. Science, 1944, 99, 183.

3. Fishman, J. B., Wilhelmi, A. E., and Russell, J. A., Crystalline pituitary protein with high growth activity. Science, 1947, 106, 402.

4. Personal communications from P. H. Forsham, A. T. Kenyon, F. C. Bartter, L. W. Kinsell, and E. Shorr. June 4th, 1949.

5. Reifenstein, E. C., Jr., Kinsell, L. W., and Albright, $F$., Observations on the use of the serum phosphorous level as an index of the pituitary growth hormone activity; the effect of estrogen therapy in acromegaly. Endocrinology, 1946, 39, 71.

6. Peters, J. P., and Van Slyke, D. D., Quantitative Clinical Chemistry. Vol. II. Williams and Wilkins Co., Baltimore, 1932.

7. Howard, J. E., and Bigham, R. S., Potassium determinations by the flame photometer. Trans. 11th Conference on Metabolic Aspects of Convalescence, Josiah Macy, Jr. Foundation, Oct., 1945, p. 9.

8. Callow, N. H., Callow, R. K., and Emmens, C. W., Colorimetric determination of substances containing the grouping $-\mathrm{CH}_{2} \cdot \mathrm{CO}-$ in urine extracts as an indication of androgen content. Biochem. J., 1938, 32, 1312.

9. Heard, R. D. H., and Sobel, H., Steroids. VIII. A colorimetric method for the estimation of reducing steroids. J. Biol. Chem., 1946, 165, 687.

10. Talbot, N., Saltzman, A. H., Wixom, R. L., and Wolfe, J. K., The colorimetric assay of urinary corticosteroid-like substances. J. Biol. Chem., 1945, 160, 535.

11. Reifenstein, E. C., Jr., Albright, F., and Wells, S. L., The accumulation, interpretation, and presentation of data pertaining to metabolic balances, notably those of calcium, phosphorous, and nitrogen. J. Clin. Endocrinol., 1945, 5, 367.

12. Forsham, P. H., Thorn, G. W., Prunty, F. T. G., and Hills, A. G., Clinical studies with pituitary adrenocorticotropin. J. Clin. Endocrinol., 1948, $8,15$.

13. Conn, J. W., and Vogel, W. C., Effects of prolonged adrenal cortical stimulation upon free and esterified serum cholesterol in normal men. J. Clin. Endocrinol., 1949, 9, 656.

14. Li, C. H., Simpson, M. E., and Evans, H. M., Influence of growth and adrenocorticotropic hormones on the body composition of hypophysectomized rats. Endocrinology, 1949, 44, 71.

15. Bartlett, P. D., and Gaebler, O. H., Anterior pituitary growth preparations: the relationship between nitrogen storage and other criteria of activity. Endocrinology, 1948, 43, 329. 